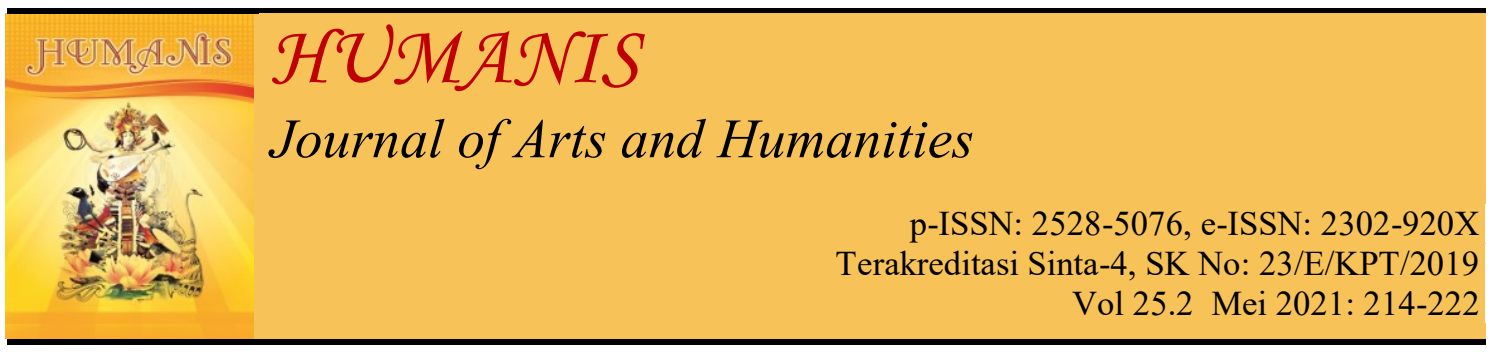

\title{
Pergulatan Perempuan dalam Revolusi Fisik di Bali
}

\author{
I Nyoman Sukiada, Anak Agung Ayu Girindra Wardani, Ni Wayan Sri \\ Rahayu \\ Universitas Udayana, Denpasar, Bali, Indonesia
}

Email korespondensi: nyomansukiada@yahoo.com, dewigirindra69@gmail.com, niwayansrirahayu@gmail.com

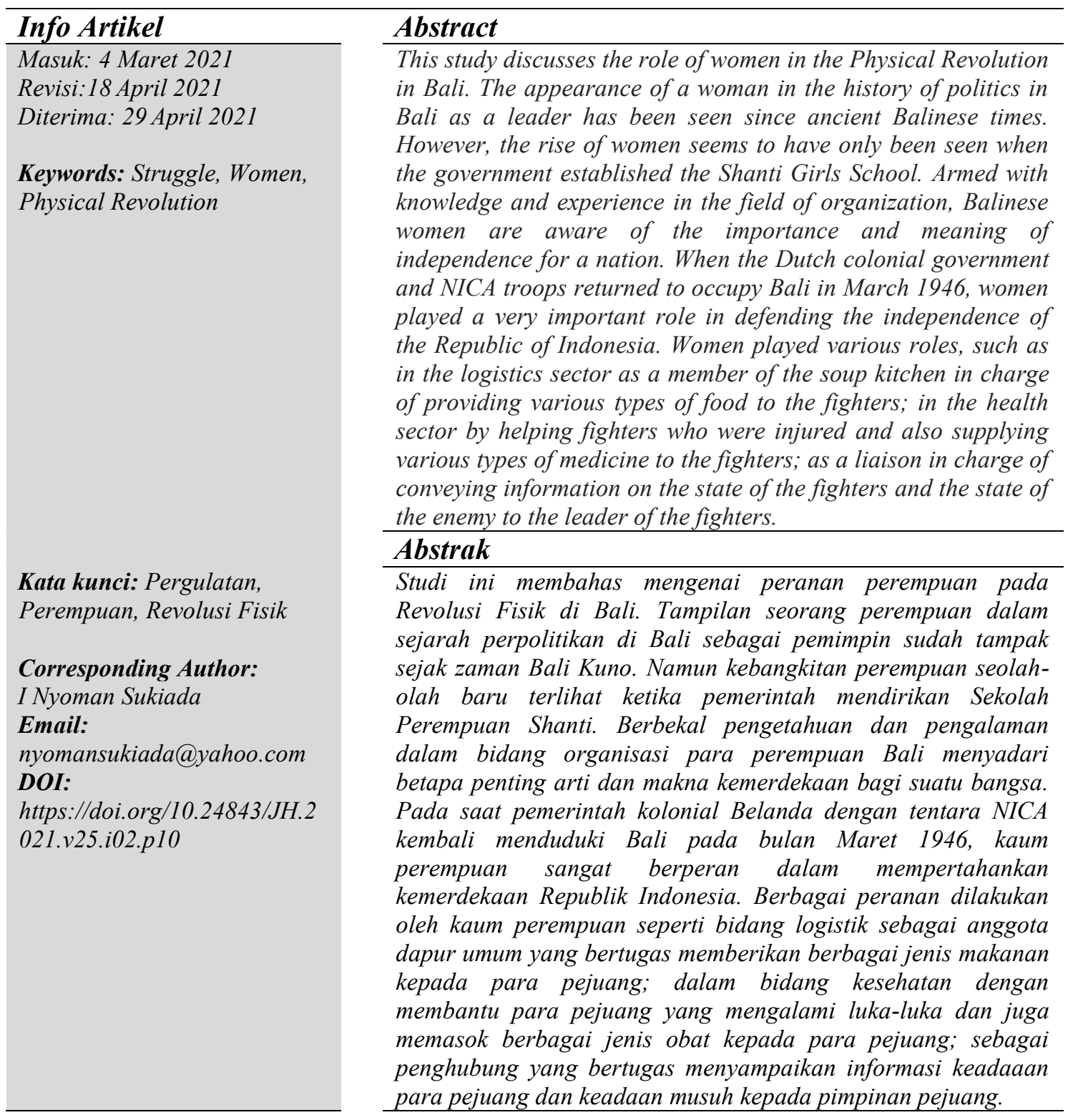




\section{PENDAHULUAN}

Kedatangan Mr. I Gusti Ketut Pudja di Bali pada tanggal 23 Agustus 1945 membawa berita proklamasi disambut antusias oleh masyarakat Bali. Di samping menyampaikan berita proklamasi Mr. Pudja juga membawa mandat pengangkatannya sebagai Gubernur Sunda Kecil dan mandat pengangakatan Ida Bagus Putra Manuaba sebagai Ketua Komite Nasional (KNI) Provinsi Sunda Kecil. Pengangkatan Mr. Pudja sebagai gubernur dan Putra Manuaba sebagai ketua KNI menunjukkan bahwa pemerintahan Republik Indonesia sudah eksis di daerah Sunda Kecil. Lagu Sorak-Sorak Bergembira dikumandangkan khususnya oleh para pemuda yang telah menghimpun diri dalam kelaskaran atau kesantrian seperti Pemuda Rakyat Indonesia (PRI), Angkatan Pemuda Indonesia (API), Pemuda Sosialis Indonesia (PSI), dan Pemuda-Pemudi Republik Indonesia (PPRI). Setelah organisasi kelaskaran terbentuk akhirnya pada tanggal 31 Agustus 1945 dibentuk Badan Keamanan Rakyat (BKR) di bawah pimpinan Made Putu sebagai representasi kekuatan rakyat yang bertugas menjaga keamanan masyarakat dalam suasana revolusi. Pada tanggal 1 November 1945 Badan Keamanan Rakyat berubah menjadi Tentara Keamanan Rakyat (TKR). Dalam waktu singkat setelah TKR terbentuk maka dibentuk juga Palang Merah Indonesia (PMI) di Singaraja di bawah pimpinan atau koordinator Nyonya Hadiwijoyo.

Pada bulan-bulan awal revolusi masyarakat Bali baik dari golongan elite modern maupun dari kalangan aristokrasi penguasa tradisional memberi dukungan terhadap revolusi Indonesia (Kahin, 1980: 5). Kegembiraan masyarakat Bali dalam menyambut dan merayakan hari kemerdekaan terusik setelah mendaratnya kapal yang mengangkut pasukan Gajah Merah di pantai Sanur pada tanggal 2
Maret 1946. Pendaratan kapal pasukan Gajah Merah membawa Pemerintahan Sipil Hindia Belanda (Nederlandsch Indies Civil Administration), suatu resimen di bawah pimpinan Kolonel Infanteri F.H. ter Meulen. Dalam waktu yang sangat singkat tentara NICA sudah bergerak ke berbagai daerah di Bali. Kelompok elite tradisional (raja-raja) yang pada awalnya bersimpati kepada proklamasi kemerdekaan akhirnya berbalik mendukung kekuasaan tentara NICA di daerahnya masing-masing.

Terjadinya situasi pro-kontra terhadap proklamsi kemerdekaan akhirnya menimbulkan gejolak di seluruh daerah Bali yang dalam pembabakan sejarah dikenal dengan masa Revolusi Fisik. Gejolak yang terjadi melibatkan golongan elite pemuda pejuang yang tergabung dalam orgaanisasi kemeliteran dan organisasi sipil sosial politik dan juga melibatkan kaum perempuan. Kesadaran kaum perempuan untuk terjun dalam kancah revolusi menarik untuk diteliti karena secara sosiokultural kaum perempuan Bali sering diberi lebel sebagai mahluk yang lemah, pasif, cengeng, emosional dan mahluk natural atau alamiah. Hal tersebut tidak selamanya benar karena kaum perempuan khususnya di Bali turut serta dalam perjuangan revolusi fisik dan berperan dalam berbagai bidang memberi andil dalam mendukung perjuangan untuk mempertahankan kemerdekaan di Bali. Oleh karena itu lah, penelitian ini penting untuk di ungkap guna mengetahui lebih dalam mengenai keterlibatan perempuan dalam mempertahnkan kemerdekaan di Bali. Sehingga tidak ada lagi anggapan bahwa perempuan adalah sosok yang lemah dan selalu membutuhkan perlindungan dari seorang laki-laki. Mengingat sejauh ini realitas mengenai kehidupan perempuan Indonesia masih banyak mengalami pengekangan, penindasan dan pembodohan terutama pengekangan yang terjadi terhadap 
perempuan Indonesia akibat persepsi yang salah terhadap peran istri dalam kehidupan rumah tangga (Safitri, 2018:1). Di lihat dari perkembangan suatu bangsa, masyarakat dan ideologi suatu negara peranan seorang perempuan tentu menjadi suatu persoalan yang sangat penting untuk dikaji dan dipahami karena pada dasarnya perempuan dan laki-laki sama-sama memiliki peranan penting untuk menciptakan masyarakat yang sosialis.

\section{METODE DAN TEORI}

Penelitian ini menggunakan metode kualitatif yang merupakan tradisi yang dikembangkan oleh ilmu-ilmu sosial dan budaya yang secara fundamental tergantung atas pengamatan manusia dalam kawasannya sendiri dan berhubungan dengan orang-orang tersebut dalam bahasa dan peristilahannya. Medote kualitatif mengikuti prosedur penelitian yang menghasilkan data deskriptif, yaitu berupa kata-kata tertulis dari perilaku yang diamati (Moleong, 2005: 3, 16). Teknik pengumpulan data dalam penelitian ini menggunakan metode wawancara dalam hal ini yakni wawancara mendalam (indepthinterview). Teknik penentuan informan dilakukan secara purposive sampling, yaitu mereka yang dipandang memiliki pengetahuan sesuai dengan topik penelitian (Moleong, 2005:16). Selanjutnya data akan di olah dengan menggunakan teknik deskriptif analisis. Pada tahap ini data-data primer yang berupa hasil wawancara digabungkan dengan data-data sekunder yang berasal dari dokumen pendukung. Melalui hasil ini dimaksudkan agar pengukuran terhadap fenomena sosial tertentu akan memunculkan deskripsi (gambaran) secara sistematis mengenai Pergulatan Perempuan dalam Revolusi Fisik di Bali

Penelitian ini menggunakan Teori Peran. Teori peran (role theory) berawal dari ilmu psikologi, sosiologi dan antropologi. Dalam ketiga ilmu tersebut, istilah "peran" diambil dari dunia teater. Dalam teater, seorang aktor harus bermain sebagai seorang tokoh tertentu dan dalam posisinya sebagai tokoh ia diharapkan untuk berperilaku secara tertentu. Bilton sebagaimana dikutip dalam Edy Suhardono menyatakan bahwa peran sosial mirip dengan peran yang dimainkan seorang aktor, maksudnya orang yang memiliki posisiposisi atau status-status tertentu dalam masyarakat diharapkan untuk berperilaku dalam cara-cara tertentu yang bisa diprediksikan, seolah-olah sejumlah "naskah" (scripts) sudah disiapkan untuk mereka. Namun harapan-harapan yang terkait dengan peran-peran ini tidak hanya bersifat satu-arah. Seseorang tidak hanya diharapkan memainkan suatu peran dengan cara-cara khas tertentu, namun orang itu sendiri juga mengharapkan orang lain untuk berperilaku dengan cara-cara tertentu terhadap dirinya (Suhardono, 2016:8). Teori ini digunakan sebagai landasan berfikir dalam mengkaji permasalahan terkait dengan peranan perempuan pada saat Revolusi Fisik yakni perempuan Bali ikut andil dalam berbagai bidang untuk mempertahankan kemerdekaan.

\section{HASIL DAN PEMBAHASAN}

\section{Kesadaran Perempuan Bali dalam Berorganisasi}

Berbicara mengenai perempuan maka pemikiran sebagian orang biasanya langsung tertuju pada aktivitas yang sering dilakukan oleh seorang perempuan seperti halnya memasak, mengurus anak, melayani suami dan berbagai pekerjaan rumah lainnya. Seorang perempuan selalu diposisikan sebagai sosok yang lemah dalam hal ini yakni sosok yang selalu membutuhkan perlindungan dari seorang laki-laki. Sehingga seorang perempuan kerap dipandang sangat tidak 
mungkin dan bahkan sangat tidak berpotensi ketika akan menunjukkan eksistensinya di luar rumah, seperti halnya kiprah prempuan di bidang politik. Bahkan hingga dengan saat ini keterlibatan perempuan dalam suatu organisasi masih diragukan dan tergolong sangat minim.

Tahun 1900an dan sebelumnya perempuan Indonesia harus menerima cara hidup yang terbatas dan diisi dengan berbagai kewajiban-kewajiban untuk keluarga dan rumah tangga dengan hak yang sangat minim. Banyak ketidakadilan dalam adat istiadat yang berlaku dalam perkawinan seperti kawin paksa dan sistem poligami (Abdullah, 2019:21).

Padahal tampilan seorang perempuan dalam sejarah perpolitikan di Bali sebagai pemimpin sudah tampak sejak zaman Bali Kuno. Hal ini dapat dilihat dari nama-nama tokoh perempuan yang tercatat dalam sejarah Bali yakni Subhadrika Dharmadewi, Cri Gunapriya Dharmapatni, Paramecwari Indujaketana, Mahadewi Cacangkajacihna, Cri Maharaja Cri Wijaya Mahadewi, Cri Sang Adnyadewi dan Cri Sakala Indukirana yang merupakan bukti bahwa peranan perempuan dalam bidang politik di Bali sudah terjadi sejak lama (Mediani, 1985: 75-81). Selain itu, nama-nama perempuan yang tampil sebagai pemimpin sejak zaman Kerajaan Hindu yakni Dewi Suhita dan Tri Bhuwana Tunggal Dewi (Parawansa, 2018:12).

Namun kiprah seorang perempuan dalam perpolitikan seakan terlupakan dan nyaris tidak muncul dipermukaan. Pada tahun 1923 seolah menjadi tonggak awal kebangkitan perempuan di Bali. Hal ini ditandai dengan didirikannya Sekolah Perempuan Shati. Pendirian Sekolah Perempuan Shanti bertujuan untuk memajukan pendidikan kalangan perempuan di Bali. Sebagian besar siswa sekolah Perempuan Shanti berasal dari golongan jaba. Hal ini tampaknya dipengaruhi oleh pandangan masyarakat terutama dari golongan triwangsa yang masih mempertahankan adat istiadat lama dan membatasi anak-anaknya bergaul dengan masyarakat kebanyakan. Salah satu paham kemajuan yang diupayakan oleh guru-guru yang mengajar di sekolah Perempuan Shanti adalah membaca lontar Bali yang berisi berbagai falsafah hidup masyarakat Bali. Hal ini dilakukan untuk mendobrak tradisi dalam masyarkat Bali yang melarang masyarakat apalagi anak-anak untuk membaca lontar dan berusaha untuk menanamkan kepercayaan kepada anak-anak dan masyarakat luas bahwa setiap orang mempunyai hak yang sama untuk mempelajari ajaran agamanya. Dengan demikian dapat dikatakan bahwa sekolah Perempuan Shanti merupakan suatu lembaga pendidikan yang dirintis oleh golongan Bumi Putra dengan prinsip swadaya untuk kemajuan Perempuan Bali. Jenjang pendidikan ini adalah persiapan untuk menempuh pendidikan di sekolah-sekolah pemerintah (Santini, 1986:31).

Berawal dari Pendirian Sekolah Perempuan Shanti, kiprah perempuan mulai semakin meningkat. Hal ini dapat dilihat dari terbentuknya organisasi Peroekoenan Istri (PI) yang dipelopori oleh seorang pemilik sekolah yang bernama Tjokorda Ngoerah Pemajoen (Madjalah Djatajoe, 1938: 357). Organisasi Peroekoenan Istri (PI) merupakan sebuah organisasi bagi para perempuan Bali yang memiliki suami pegawai.

Selanjutnya pada tahun 1938 Organisasi Peroekoenan Istri (PI) mengalami perkembangan hingga mampu menyewa sebuah ruangan di sekolah Kampung Tiga Denpasar untuk dijadikan sekretariat dan sebagai tempat untuk melaksanakan berbagai aktivitas. Namun Organisasi Peroekoenan Istri (PI) ternyata belum mampu mengangkat taraf hidup masyarakat Bali khususnya kaum 
perempuan secara keseluruhan karena lingkup kerja PI hanya terbatas di lingkungan pegawai negeri. Tokoh-tokoh perempuan Bali yang telah berhasil menyelesaikan pendidikan di luar Bali memperhatikan bahwa aktivitas organisasi Peroekoenan Istri sangat terbatas. Muncul gagasan dari tokohtokoh perempuan Bali pada waktu itu untuk membentuk sebuah organisasi perempuan yang gerakannya mampu menjangkau seluruh lapisan masyarakat. Pada tanggal 1 Oktober 19365 orang guru perempuan yakni Goesti Aju Rapeg, A.A. Rai, Ni Ktut Setiari, Ni Luh Kenteng, dan Made Tjatri mengadakan pertemuan di Puri Belaluan Denpasar (Santini, 1986: 99). Dalam pertemuan itu dibicarakan kemungkinan untuk mendirikan organisasi perempuan. Kesepakatan yang berhasil diwujudkan pada pertemuan itu akhirnya melahirkan suatu organisasi perempuan yang bernama Putri Bali Sadar (PBS) (Pemajoen, 1937: 181). Sesuai dengan nama organisasi Putri Bali Sadar, organisasi ini bertujuan untuk meningkatkan kesadaran kaum perempuan khususnya di Bali akan hak dan kewajibannya sebagai perempuan dalam memperjuangkan kemerdekaan dengan jalan meningkatkan pendidikan untuk masa depan yang lebih cerah (Njonja Merta, 1983: 103).

Dari hal tersebut dapat dilihat bahwa seorang perempuan Bali sesungguhnya memiliki potensi besar ketika ingin menunjukkan kiprahnya di luar. Namun saat ini kadang ketika seorang perempuan akan menunjukkan kiprahnya di bidang politik sering kali tidak mendapatkan kepercayaan dari seorang laki-laki maupun kepercayaan di masyarakat. Anggapan bahwa seorang perempuan lemah maupun perempuan hanya bertugas dalam urusan domestik masih terbawa hingga dengan saat ini. Padahal jika dilihat dari sejarahnya kiprah perempuan sesungguhnya sudah muncul sejak zaman Bali Kuno.

\section{Perempuan Bali Dalam Menyambut Kemerdekaan}

Proklamasi Kemerdekaan Indonesia diproklamirkan atas nama bangsa Indonesia oleh IR.Sukarno yang didampingi DRS. Mohammad Hatta pada tanggal 17 Agustus 1945 di Jalan Pegangsaan Timur No.56 Jakarta pada pukul 10.00 WIB (Pidada, 2018:9). Dalam waktu singkat berita tentang proklamasi kemerdekaan Indonesia bergema ke seluruh penjuru tanah air termasuk ke Pulau Bali. Kedatangtan Mr. I Gusti Ketut Pudja di Kota Singaraja pada tanggal 23 Agustus 1945 setelah diangkat menjadi Gubernur Sunda Kecil membawa dua keputusan dari pemerintah pusat. Pertama, menyampaikan kepastian berita proklamasi kemerdekaan Indonesia pada tanggal 17 Agustus 1945. Kedua, menyampaikan mengenai pengangkatan Ida Bagus Putera Manuaba menjadi Ketua Komite Nasional Indonesia (KNI) untuk wilayah Sunda Kecil (Wirawan Dkk, 2017: 11).

Masyarakat di Kota Singaraja sebagai salah satu pusat pemerintahan di Bali segera bangkit bergerak menyambut kemerdekaan, pekik merdeka bergema di seluruh pelosok kota bahkan sampai ke desa-desa. Kantor-kantor pemerintah secara serentak menaikkan bendera merah putih sekalipun pada waktu itu pemerintah Jepang masih tetap memegang kendali pemerintahan di Bali. Dalam suasana revolusi yang sangat bergejolak menjadi momentum bagi para pemuda dan pemudi untuk ikut memberi sumbangsih kepada bangsa dan negara. Di Kota Singaraja muncul seorang perempuan yang umurnya masih sangat muda bernama Analis yang berasal dari Kota Bantaeng Sulawesi Selatan. Orang tuanya telah lama bermukim di Kota Singaraja, hidup dari usaha warung nasi, sedangkan Analis sendiri bekerja di 
Kantor Pos Singaraja. Sosok Analis merupakan figur perempuan yang memberi semangat bagi kaum perempuan di Kota Singaraja untuk ikut berpartisipasi dalam membantu perjuangan para pemuda. Kaum perempuan yang ikut dalam organisasi perjuangan pada waktu itu diantaranya Wayan Gunung Sukarti (Djero Wiladja), Luh Sudarmi, Gustu Ayu Sukesi, Luh Parmi, Wirasni, Nariasih, Luh Taman dan banyak lagi yang lainnya. Kaum perempuan membantu para pemuda pejuang secara serentak bergerak, ada yang menuju arah timur ke Desa Sangsit, Bungkulan, Kubutambahan, Tejakula; ada pula yang bergerak ke arah Barat menuju desa Banjar, Bubunan, Seririt dan ke daerah lain. Tugas mereka adalah memberikan penerangan kepada masyarakat dan menyadarkan masyarakat bahwa bangsa Indonesia sudah merdeka dan mengajak masyarakat di desa-desa yang didatangi untuk mempersiapkan diri dan ikut bersama-sama, bergotong royong mempertahankan kemerdekaan.

Lagu Sorak-Sorak Bergembira dikumandangkan khususnya oleh para pemuda yang telah menghimpun diri dalam organisasi kepemudaan seperti Angkatan Muda Indonesia (AMI) di bawah pimpinan Tjokorda Sudarsana. Ketika AMI dipimpin oleh Gde Puger AMI Singaraja diubah namanya menjadi Pemuda Sosialis Indonesia (Pesindo). Pemuda Republik Indonesia (PRI) dan Pesindo secara bersama-sama mendukung proklamasi kemerdekaan Republik Indonesia. Dalam waktu yang singkat kedua organisasi ini dengan cepat melebarkan sayapnya ke daerah-daerah lain seperti Gianyar, Tabanan, dan Jembrana (Pendit, 1979: 70-71).

Dari hal tersebut dapat diketahui bahwa baik laki-laki maupun perempuan sama-sama memiliki peranan yang sangat penting dalam kemerdekaan Indonesia. Sehingga tidak terdapat ungkapan kembali bahwa perempuan adalah sosok yang lemah dan yang lainnya. Montagu dalam (Sadili, 1988:33) mengemukakan bahwa sifat-sifat psikologis wanita membuktikan lebih unggul daripada lakilaki. Selain itu terdapat fakta-fakta yang membuktikan bahwa wanita adalah organisme yang secara biologis lebih unggul, unggul dalam arti menikmati nilai kelangsungan hidup yang lebih tinggi daripada pria berkat sifat-sifat biologisnya.

\section{Peranan Perempuan Dalam Revolusi Fisik di Bali}

Tanggal 2 Maret 1946 di Pantai Sanur pada pagi hari dalam suasana pantai yang sangat tenang, tiba-tiba tampak iring-iringan kapal pasukan Gajah Merah mendarat dengan angkuhnya. Pasukan Gajah Merah merupakan satu kesatuan alat pemerintah NICA (Netherlands Indies Civil Administration), Pemerintah Civil Hindia Belanda. Kesatuan ini adalah satu Resimen di bawah komando Letnan Kolonel Infanteri F.H. ter Meulen (Pendit, 2008: 156). Dalam waktu yang singkat tentara NICA sudah menguasai hampir seluruh wilayah di Bali termasuk Kota Singaraja sebagai pusat pemerintahan. Di Kota Singaraja perilaku tertara NICA semakin mengganas, demikian juga di pihak para pemuda pejuang juga semakin berani menantang tentara NICA. Dalam situasi seperti itu sering terjadi kontak senjata antara tentara NICA dengan para pemuda pejuang yang menimbulkan banyak korban. Dalam kondisi seperti inilah peranan anggota Palang Merah Indonesia sangat dibutuhkan terutama dalam merawat dan member bantuan obatobatan kepada para pemuda pejuang. Salah satu tokoh perempuan yang memiliki peranan dalam bidang kesehatan yakni Gunung Sukerti. Pada bulan Desember 1946 Gunung Sukerti dilantik dan disumpah menjadi informan dan membantu perjuangan oleh 
Kompiang Sujana yang pada saat itu menjabat sebagai pimpinan Markas Besar Dewan Perjuangan Rakyat Indonesia Sunda Kecil Buleleng. Semua tugas yang dibebankan kepada Gunung Sukarti harus dilaksanakan secara rahasia dan penuh disiplin. Tugas lain yang diemban oleh Gunung Sukarti adalah mendistribusikan segala sesuatu yang dibutuhkan oleh para pejuang yang ada di pedalaman seperti halnya obat-obatan sesuai permintaan para pejuang. Atas kegigihan dan keberhasilannya dalam mengemban tugas-tugas yang diberikan, selanjutnya pada pertengahan tahun 1947 Gunung Sukarti dan Luh Sudarmi mendapat tugas baru sebagai sekretaris dan pengurus PMI di Markas Besar Daerah Buleleng di bawah pimpinan Wayan Nur Rai alias Pak Mangku. Rekannya Luh Sudarmi bertugas di bidang pendidikan memberikan penerangan kepada masyarakat khususnya kaum perempuan di daerah pedesaan dan menanamkan pengetahuan tentang arti penting kemerdekaan bagi Bangsa Indonesia. Tugas yang diemban oleh Luh Sudarmi sangat cocok karena profesi Luh Sudarmi sebagai guru sehingga tugas yang diembannya dapat berjalan dengan baik. Kedua sosok perempuan ini masuk ke pelosok-pelosok desa untuk memberikan pemahaman bahwa masyarakat hendaknya mulai menyadari arti penting pendidikan, kesehatan, dan kemerdekaan. Dengan pemahaman ini diharapkan masyarakat di desa-desa tergerak hatinya untuk mendukung perjuangan para pejuang dalam mempertahankan kemerdekaan.

Selain berperan dalam bidang kesehatan dan pengajaran, pada masa Revolusi Fisik para perempuan Bali juga memiliki peranan yang sangat penting dalam bidang logistik. Banyak perempuan yang tergabung dalam bidang perjuangan khususnya dalam bidang konsumsi. Salah satunya adalah Ni Wayan Munak yang berasal dari Desa
Selat Abiansemal Kabupaten Badung. Dalam penyusunan dan persiapan siasat penyerangan terhadap tangsi Baha, Ni Wayan Munak berperan dalam penyiapan logistik dan konsumsi. Pada rapat-rapat persiapan penyerangan terhadap tangsi Baha beliau bertugas sebagai konsumsi dan beberapa kali bertugas sebagai matamata. Dalam tugasnya sebagai mata-mata para pejuang, Ni Wayan Munak menyamar menjadi tukang nyapung (berburu capung) apabila tugas mematamatai musuh dilaksanakan di lingkungan desa Selat. Apabila bertugas mematamatai musuh di luar desa, maka $\mathrm{Ni}$ Wayan Munak menyamar menjadi tukang munuh (tukang sabit) rumput untuk makanan ternak. Selain itu, Di daerah Bangli seorang pejuang perempuan yang bernama $\mathrm{AAB}$ Made Rai, merupakan sosok perempuan yang konsisten membantu perjuangan khususnya membantu dalam bidang logistik. Dari hal tersebut dapat dilihat bahwa para Perempuan Bali juga memiliki keberanian serta semangat yang kuat dalam mempertahnkan kemerdekaan di Bali. Sifat keberanian para perempuan Bali dapat dilihat dari peranannya sebagai mata-mata seperti yang dilakukan oleh Ni Wayan Munak yang menjadi penghubung dan memberikan informasi yang dapat membantu para pejuang dalam mengetahui keadaan musuh maupun keadaan perjuangan.

Dalam masa pembangunan dan perjuangan bangsa Indonesia terutama pada masa-masa revolusi fisik, seluruh lapisan masyarakat pada umumnya ikut serta bahu membahu bersama-sama para pemuda dan kaum perempuan turut serta terjun dalam kancah perjuangan mempertahankan kemerdekaan bersama para pejuang lainnya. Mereka mengabdikan seluruh hidupnya untuk kepentingan rakyat dan bangsa yang dicintainya, dan sudah diakui tanpa keikutsertaan para perempuan di medan laga tentu tidak akan dapat berhasil 
dengan baik. Namun keikutsertaan kaum perempuan dalam kancah perjuangan tidak terekspos secara luas jika dibandingkan dengan kaum pria. Dengan demikian, perlu kaum perempuan yang terekpose dan tercatat dalam perjuangan bangsa, gamblang dan mendalam. Maka jika membicarakan kaum hawa, kita tidak akan lepas dari peran mereka pada masa lampau dan masa kini.

\section{SIMPULAN}

Kemajuan pendidikan yang dialami oleh masyarakat Bali ternyata membawa pengaruh besar terhadap kaum perempuan. Walaupun pada awalnya kebutuhan pendidikan kaum perempuan diperjuangkan oleh kaum laki-laki namun pada akhirnya menyadarkan kaum perempuan untuk turut serta bersamasama berjuang untuk membebaskan kaumnya dari keterbelakangan. Kaum perempuan Bali mempunyai hak dan kewajiban yang sama untuk membebaskan rakyat dari cengkeraman penjajah. Dengan demikian kaum perempuan giat menempuh pendidikan modern karena disadari bahwa pendidikan modern adalah salah satu sarana untuk menyadarkan masyarakat terhadap hak dan kewajibannya.

Setelah beberapa orang perempuan Bali menyelesaikan pendidikan di luar Bali mereka merasa kaumnya jauh tertinggal dari perempuan-perempuan di daerah lain. Disadari bahwa perjuangan tidak akan mungkin berhasil jika dilakukan secara individual maka kebutuhan akan organisasi modern sangat mendesak. Kondisi inilah yang menyadarkan kaum perempuan Bali untuk terus berpartisipasi dalam upaya mempertahankan kemerdekaan di Bali pada masa revolusi fisik.

Berbekal pengetahuan dan pengalaman dalam bidang organisasi para perempuan Bali telah menyadari betapa penting arti dan makna kemerdekaan bagi suatu bangsa. Pada saat pemerintah kolonial Belanda dengan tentara NICA kembali menduduki Bali pada bulan Maret 1946, semangat masyarakat Bali khususnya kaum perempuan saling bahu membahu berusaha mempertahankan kemerdekaan Republik Indonesia yang telah diproklamasikan pada tanggal 17 Agustus 1945. Berbagai peranan dilakukan oleh kaum perempuan seperti bidang logistik sebagai anggota dapur umum yang bertugas memberikan berbagai jenis makanan kepada para pejuang; dalam bidang kesehatan dengan membantu para pejuang yang mengalami luka-luka dan juga memasok berbagai jenis obat kepada para pejuang; sebagai penghubung yang bertugas menyampaikan informasi keadaaan para pejuang dan keadaan musuh kepada pimpinan pejuang.

\section{DAFTAR PUSTAKA}

Abdullah, A. F. A. (2019). Perempuan Indonesia sampai awal abad ke-20. ENTITA: Jurnal Pendidikan Ilmu Pengetahuan Sosial dan Ilmu-Ilmu Sosial, 1(1), 19-28.

Meleong, Lexy J. (2005). Metodologi Penelitian Kualitatif. Bandung: PT. Remaja Rosdakarya.

Ni'mah, K. (2020). Diskriminasi Gender dalam Novel Tarian Bumi Karya Oka Rusmini (Doctoral dissertation, universitas jambi).

Parawansa, K. I. (2003). Pemberdayaan perempuan dalam pembangunan berkelanjutan. Bali, hlm, 1-15.

Pendit, S. (1979). Bali Berjuang. Jakarta: Gunung Agung.

Pidada, I. B. A. (2018). Bentuk-Bentuk Tindakan Belanda Terhadap Pejuang Pada Masa Revolusi Fisik Di Bali. 
Kulturistik: Jurnal Bahasa dan Budaya, 2(1), 9-18.

Ratja, Ida Bagus. (2013). Revolusi Fisik di Bali 1946-1949. Denpasar: Pemerintah Provinsi Bali Biro Kesejahteraan Rakyat Sekretariat Daerah Provinsi Bali. Agung, A.A. Gde Putra Dkk. 1992/1993. Sejarah Revolusi Kemerdekaan Daerah Bali. Jakarta: Departemen Pendidikan dan Kebudayaan.

Sadiah, S. (2018). Peranan Ny. Sumarsih Yati Arudji Kartawinata Dalam Laskar Wanita Indonesia (LASWI) Tahun 1945-1949 (Doctoral dissertation, Universitas Islam Negeri" Sultan Maulana Hasanuddin" Banten).

Sadili, Saparinah. (1988). Pengembangan Diri Wanita dalam Keluarga dan Lingkungan Sosial. Jakarta. Djambatan.

Sadili, Saparinah. (1995). "Pengantar Tentang Kajian Perempuan", dalam T.O. Ibromi (Ed.), Kajian Perempuan Dalam Pembangunan. Jakarta: Yayasan Obor Indonesia.

Safitri, A. (2018). Pemikiran Soekarno Tentang Perempuan (Doctoral dissertation, Universitas Islam Negeri" Sultan Maulana Hasanuddin" Banten).

Sondarika, Wulan. (2017). Peran Wanita Dalam Perjuangan Kemerdekaan Indonesia Masa Pendudukan Jepang. Jurnal Historia. Vol. 5 No. 2.Hlm 23374712.

Suhardono, Edy. (2016). Teori Peran: Konsep, Derivasi dan Implikasinya. Jakarta: Gramedia Pustaka Utama.

Sukiada, I. N. Politik Gender Orde Baru Dan Keterpinggiran Perempuan Bali Dalam Kancah Politik.
Sumaryani, N. M., \& Rahayu, N. W. S. (2020). Chāndogya Upaniṣad: Pengetahuan Esensial Dari Veda. Vidya Darśan: Jurnal Filsafat Hindu, 2(1), 36-43.

Tirtayasa, I Gusti Bagus Meraku Dkk. (2000). Sejarah Perjuangan Kemerdekaan Rakyat Buleleng 19451950. Bandung: Ganesa Exact.

Tirtayasa, I Gusti Bagus Meraku. (1994). Bergerilya Bersama Ngurah Rai. Denpasar: Bali Post.

Wirawan, A. A. Bagus Dkk. (2017). Inventarisasi Peristiwa dan Tokoh Sejarah. Denpasar: Dinas Kebudayaan Provinsi Bali. 